\title{
Centronuclear myopathy
}

INSERM

\section{Source}

INSERM. (1999). Orphanet: an online rare disease and orphan drug data base.

Centronuclear myopathy. ORPHA:595

Centronuclear myopathy (CNM) is an inherited neuromuscular disorder characterized by clinical features of a congenital myopathy and centrally placed nuclei on muscle biopsy. 